\title{
Guarantee of the Right to Silence and of the Right not to Contribute to One's Own Incrimination in Romanian Law
}

\author{
Carmen Adriana Domocos \\ University of Oradea, Faculty of Law
}

Received 29 May 2018 - Revised 29 June 2018 • Accepted 19 July 2018

\begin{abstract}
The right to silence enjoys increased attention from the Romanian legislator and is currently regulated by the Criminal Procedure Code (Law no. 135/2010), which entered into force on $1^{\text {st }}$ February 2014. The right to silence (to remain silent) and the right not to contribute to one's own incrimination (the privilege against self-incrimination) are the implicit procedural guarantees of the right to a fair trial, which results from the case law of the European Court of Justice within the meaning of Article 6 paragraph 1 of the European Convention on Human Rights. They are also stipulated in the field of preventive measures. For the first time, the New Code of Criminal Procedure also regulates the witness's right not to incriminate himself. The paper contains also some considerations about the purpose of the privilege of silence within the meaning of the ECHR.
\end{abstract}

Keywords: the right of silence, the privilege against self-incrimination, procedural guarantees, witness' right not to incriminate himself.

1. Introductory issues regarding the right to silence and to non-self-incrimination

The right to silence (to remain silent) is the implicit procedural guarantee of the right to a fair trial, which results from the case law of the European Court of Justice within the meaning of Article 6 paragraph 1 of the European Convention on Human Rights, according to which judicial authorities cannot oblige a perpetrator (suspected of having committed a criminal offence), a suspect or a defendant to make statements, while having, however, a limited power to draw conclusions against them, from their refusal to make statements.

The right not to contribute to one's own incrimination (the privilege against selfincrimination) is the implicit procedural guarantee of the right to a fair trial, which results from the case law of the European Court of Justice within the meaning of Article 6 paragraph 1 of the European Convention, according to which judicial bodies or any other state authority cannot oblige a perpetrator (suspected of having committed a criminal offence), a suspect, a defendant or a witness to cooperate by providing evidence which might incriminate him or which could constitute the basis for a new criminal charge. Such persons may refuse to make statements, answer questions, or hand over written documents, objects that might incriminate them (nemo debet prodere se ipsum - no one is obliged to accuse himself).

Thus, unlike the former regulation from which only the essence of those rights

(C) Authors. Terms and conditions of Creative Commons Attribution 4.0 International (CC BY 4.0) apply. Correspondence: Carmen Adriana Domocos, e-mail: carmendomocos@gmail.com. 
resulted $^{1}$, upon entry into force of the New Criminal Procedure Code, the right to silence and the privilege against self-incrimination that had already been guaranteed in the case law of the European Court of Justice acquired an appropriate regulation meant to agree with the nature and purpose of the conventional guarantee.

According to Art. 70 par. (2) of the former Criminal Procedure Code, the suspect or the defendant is informed about the deed that makes up the subject matter of the case, the legal classification thereof, the right to have a defender, as well as the right not to make any statement, while also being informed about the fact that everything he declares may be used against him, as well. If the suspect or the defendant makes a statement, he is asked to declare everything he knows about the deed and about the accusation being brought against him.

The new Criminal Procedure Code provides, in Art. 83 letter (a), as the primary right of the suspect or defendant, "the right not to make any statement during the criminal proceedings, their attention being drawn to the fact that their refusal to make any statements shall not cause them to suffer any unfavourable consequences, and that any statement they do make may be used as evidence against them".

Also in order to guarantee the right to silence, Art. 109 par. (3) of the new Criminal Procedure Code provides that if, during the hearing, the suspect or defendant exercises his right to silence (to remain silent) in respect of any of the facts or circumstances about which he is being asked, the hearing will no longer be continued, and a report of the hearing will be drawn up.

The right not to make any statements is also stipulated in the field of preventive measures. According to Art. 143 par. (3) of the Criminal Procedure Code, "the prosecutor or the criminal investigation body shall inform the suspect or defendant of his right to appoint a defender. He shall also be made aware of his right to make no statement, his attention being drawn to the fact that anything he declares may be used against him, as well".

In the same sense, Art. 225 par. (8) of the New Criminal Procedure Code provides that, prior to proceeding to the hearing of the defendant, the Judge for Rights and Liberties shall inform him of the offence of which he is accused and of his right not to make any statements, drawing his attention to the fact that anything he declares may be used against him.

According to Art. 374 of the New Criminal Procedure Code and Art. 322 of the former Criminal Procedure Code, the president of the panel of judges, after reading the writ of summons, shall explain to the defendant what charges are brought against him and shall inform the defendant about the right not to make any statement, drawing his attention to the fact that what he declars may also be used against him.

Article 375 par. (5) of the New Criminal Procedure Code and Art. 325 par. (2) of the former Criminal Procedure Code provide that, in the course of the judicial investigation, if the defendant refuses to make statements, the court shall order the reading of the statements he has previously made.

For the first time, the New Code of Criminal Procedure also regulates in Art. 118 the

\footnotetext{
${ }^{1}$ The doctrine has unanimously considered that the rule laid down in the former Criminal Procedure Code concerned the right to silence. In this respect, see Gr. Theodoru, Drept procesual penal (Criminal Procedural Law), $3^{\text {rd }}$ Edition, Hamangiu, Bucharest, 2013: 364-365; I. Neagu, Drept procesual penal. Partea generală Tratat (Criminal Procedural Law. The General Part. A Treatise), Global Lex, Bucharest, pp. 376-377; A. Crişu, Drept procesual penal (Criminal Procedural Law), $2^{\text {nd }}$ Edition, Hamangiu Publishing House, Bucharest, 2011, pp. 220-221; I. Griga and M. Ungureanu, Dreptul la tăcere al învinuitului sau inculpatului (The Right to Silence of the Accused or the Defendant), in R.D.P. (Criminal Law Journal) no. 1/2005: 37-42; M. Duţu, Semnificaţiile procedural penale ale dreptului la tăcere (The Criminal Procedural Significance of the Right to Silence), in Dreptul (Law), no. 12/2004, pp. 173-188.
} 
witness's right not to incriminate himself, according to which " $a$ witness statement given by a person who, in the same case, had the capacity of suspect or defendant prior to such testimony or acquired it subsequently, may not be used against him".

Therefore, the Romanian legislator makes reference to the privilege against selfincrimination in relation to two of the forms in which the right to silence is manifested: the right of the suspect or the defendant not to make any statements and the right of the witness not to incriminate himself.

Article 6 paragraph 1 of the European Convention implicitly guarantees two distinct rights: the right to silence and the right not to contribute to one's own incrimination.

It has been stated in the doctrine ${ }^{2}$ that "the two guarantees must be regarded as representing two notions that only partially overlap each other. The right to silence is narrower, in that it only refers to verbal communication, the right not to speak. The right to non-selfincrimination is clearly more comprehensive, because it is not limited to verbal expression, protecting individuals also against the obligation to deliver documents".

On the other hand, with regard to other issues, the scope of the right to silence is wider than the right to avoid self-incrimination, as it does not protect individuals only against the obligation to make statements to their own detriment, but also against the obligation to make any kind of statements. Practice has shown that sometimes even seemingly unimportant or insignificant questions are particularly risky for an accused. If he is not careful, there is a greater risk of making involuntary confessions or contradictory statements. These can be used to weaken the suspect's position and may affect the credibility of his statements on key issues. It is therefore important for the right to silence to be guaranteed in its "pure and absolute form, not according to a rigid and literal interpretation of the texts".

It has been shown in the case law 3 that the obligation imposed by the legislator on the person who has committed a car accident not to leave the scene of the accident is not equivalent to a violation of the privilege against self-incrimination. In the case in question, it was considered that the stay at the accident scene of the defendant who was accused of robbery (stealing a car by using violence), driving without a license and leaving the accident scene (all deeds being committed on the same evening) was not equivalent to a self-denunciation or self-incrimination with regard to the first two offences.

The right to silence does not include a person's right not to give information about his own identity (the right to anonymity4). In this respect, Art. 107 par. (1) of the New Criminal Procedure Code (Art. 70 par. (1) of the former Criminal Procedure Code) provides that the suspect or defendant, before being heard, is asked about their surname and first name, nickname, birth date and place, surname and first name of their parents, their citizenship, education, military status, working place, occupation, address where they actually live, their criminal record, as well as any other data intended to establish their personal status.

\section{Procedural guarantees}

The guarantee of the right not to make any statement is accompanied by the warning

\footnotetext{
${ }^{2}$ S. Trechsel, Human Rights in Criminal Proceedings, Oxford: Oxford University Press, 2006: 342.

3 See The High Court of Cassation and Justice of Romania (I.C.C.J.), Criminal Division, Decision no. 1877/2003, available on the website www.scj.ro

4 For a detailed analysis, see S. Trechsel, op. cit., 354-355.
} 
procedure $^{5}$, which implies the obligation of the authorities to draw the attention of the suspect or defendant to the fact that what he declares may also be used against him. This procedure is derived from the case law of the US law courts, known as "the Miranda warning" or "the Miranda rules"6.

If the suspect or defendant decides to make statements in the case or to cooperate with the judicial bodies in order to determine the truth, his attitude may be considered as a mitigating judicial circumstance?.

If, in the course of the trial, the defendant refuses to make statements, invoking the right to silence, the court shall order the reading of the statements he has previously made. The reading of the statements by the judge is not a violation of the defendant's right to silence, provided that such statements have been obtained in the absence of any "inappropriate constraints". Through this procedural attitude, the defendant cannot rule out the possibility for the judge of the case to assess previously administered statements in accordance with the principles of procedural fairness. However, the court will not have the possibility to draw conclusions about the guilt of the defendant from his remaining silent.

At E.U. level, interest has been expressed towards the harmonization of the means of guaranteeing the rights of persons suspected to have committed an offence at the time of their being deprived of their liberty, in view of reducing judicial errors and breaches of the provisions of the European Convention. Thus, Art. 14 of the Proposal for an E.U. Council Framework Decision on certain procedural rights granted in the criminal proceedings throughout the E.U. ${ }^{8}$ provides for the need to hand over to the person suspected of committing an offence, as soon as possible before the first hearing, a printed standardized document drawn up in a language he knows (statement of rights) in which the fundamental rights he enjoys should be mentioned in a simple and accessible form.

In light of these considerations, we believe that simply bringing to the knowledge of the suspects and defendants their right not to make statements is an insignificant application of the right to silence, which restricts excessively the scope of the conventional protection.

We consider that, in order for the requirements imposed by the European Court to be

\footnotetext{
5 For a detailed analysis of the warning procedure, see D. Ionescu, Procedura avertismentului. Consecinţe în materia validităţii declaraţiilor acuzatului în procesul penal (The Warning Procedure. Consequences for the Validity of the Accused's Statements in the Criminal Trial), in C.D.P. (Criminal Law Notebooks), no. 2/2006, pp. 11-62.

${ }^{6}$ See the Supreme Court of the United States of America, judgment of 13 July 1966, in the case Miranda v. Arizona, available on the website www.supremecourtuk.gov. For a detailed analysis, see W. R. LaFave \& J. H. Israel, Criminal Procedure, $2^{\text {nd }}$ edition, West Publishing Co., 1992: 313-351. Analyzing in detail this judgment, D. Ionescu states that "the decision in the Miranda case was based on the following considerations: (1) it is the right to silence, not the theory of voluntary statements, which constitutes a primary criterion in the checking of the validity of statements; (2) the object of the right to silence is not the reliability of the evidence, but the right of free option; (3) the test of verification based on this criterion concerns not the voluntary nature but the constraint exercised by the judicial bodies; (4) constraint is considered objectively, regardless of the mental state of the accused and of the manner in which he perceived the constraint" (D. Ionescu (2006). Procedura avertismentului. Consecinţe în materia validităţii declaraţiilor acuzatului în procesul penal [The warning procedure. Consequences for the validity of the accused's statements in the criminal trial]. C.D.P. (Criminal Law Notebooks), No. 2, 28).

7 According to Art. 75 letter (c) of the Criminal Code, the attitude of the offender after committing the criminal offence, resulting from presenting himself before the authorities, a truthful behaviour throughout the proceedings, the facilitation of the discovery or arrest of the participants, constitutes a mitigating judicial circumstance.

${ }^{8}$ Available on the website http://eur-lex.europa.eu.
} 
fulfilled, the criminal prosecution bodies and the courts have the obligation to notify the suspects, defendants and witnesses of their right to silence, as well as of the privilege against selfincrimination, in addition to the rights provided for by Art. 83 letter (a) of the New Criminal Procedure Code (Art. 70 par. (2) of the former Criminal Procedure Code), respectively by Art. 225 par. 8 of the New Criminal Procedure Code (Art. 143 par. (3) of the former Criminal Procedure Code).

On the other hand, as is clear from the case-law of the European Court of Justice and from Art. 118 of the New Criminal Procedure Code, the witness, too, enjoys the right to silence and the right not to contribute to his own incrimination, insofar as the statement he makes might be self-incriminating. For example, in cases where, as a result of successive severances, a suspect or defendant in the initial file (the parent file) becomes a witness in a case file severed therefrom, and, in this capacity, he enjoys the right to silence and the right to avoid self-incrimination with regard to issues which, once they have been reported, might incriminate him in the case file in which he is accused. In this respect, we consider that the judicial bodies who find that the witness might incriminate himself through the statement he makes have the obligation to suspend the hearing and to communicate to the witness the fact that he has the right to remain silent and that, on the basis of the statements by which he incriminates himself, criminal prosecution could be initiated against him.

The sanction for not informing the witness, suspect or defendant of their right to silence and of the privilege against self-incrimination is the exclusion of the illegally or unfairly obtained evidence, according to Art. 102 par. (2) of the New Criminal Procedure Code (64 par. (2) of the former Criminal Procedure Code), both in the case of the hearing during the criminal prosecution and in the case of the hearing in the judicial investigation phase 9 .

The exclusion of evidence is a specific procedural sanction, applicable in the matter of evidence produced in violation of the principle of legality, loyalty, as well as in cases where the fundamental rights and liberties guaranteed by the European Convention ${ }^{10}$ have been significantly and substantially violated, to such an extent as to affect the fairness of the procedure. There is a special scope of implementation for this sanction, which is thus distinct from the sanction of nullity applicable to trial or procedural steps.

As a result, in the Cesnieks $v$. Latvia ${ }^{11}$ case, it was established that the use in the criminal proceedings of evidence obtained by violating one of the fundamental rights provided for by the Convention always raises issues related to the fairness of the criminal proceedings, even if the admission of such evidence was not decisive in the rendering of the decision to convict a person. Therefore, the use in the trial of statements obtained in violation of Art. 3 and Art. 6 of

\footnotetext{
9 In the same sense, M. Duţu (2004), Semnificaţiile procedural penale ale dreptului la tăcere [The Criminal Procedural Significance of the Right to Silence], Dreptul (Law), No. 12, 184, D. lonescu, op. cit., 44-62; I. Griga \& M. Ungureanu (2005), Dreptul la tăcere al învinuitului sau inculpatului [The right to silence of the accused or the defendant], Revista Drept Penal (Criminal Law Journal), No. 1, 41. As regards the applicability of the relative nullity sanction, see: I. Neagu (2015), Drept procesual penal. Partea generală [Criminal procedural law. The general part], Op. cit., 376-377; A. Crişu (2011), Drept procesual penal [Criminal procedural law], $2^{\text {nd }}$ Edition, Bucharest, Hamangiu Publishing House, 220-221; The High Court of Cassation and Justice of Romania (ICCJ) (2006), Criminal Division, Decision No. 828, available on the website www.scj.ro.

${ }^{10}$ For a detailed analysis of the regulation of the institution of evidence exclusion at European level, see the study conducted by the EU Network of Independent Experts on Fundamental Rights, Opinion on the Status of Illegally Obtained Evidence in Criminal Procedures in the Member States of the European Union, available on website www.europa.eu.

${ }^{11}$ The European Court of Human Rights, Case Cesnieks v. Latvia, judgment of 11 February 2014, available on the website www.echr.coe.int.
} 
the Convention entails the invalidity of the entire judicial procedure (El Haski v. Belgium case).

In the case of a hearing held for the adoption of a preventive measure, without the right to silence and to avoid self-incrimination being brought to the knowledge of the suspect or defendant, we consider that we are not dealing with a situation of absolute or relative nullity ${ }^{12}$, but still with that of the exclusion of unlawfully produced evidence, given that these are guarantees against the unlawful or unfair production of evidence. The hearing required upon adopting preventive measures must always be carried out in the presence of a chosen or public (ex officio) defender, the latter being necessary in order to provide effective defense for the suspect or defendant. In this way, we consider that the situation of a procedural harm which could entail nullity is avoided.

As far as we are concerned, we think that the data and information resulting from such a statement cannot be used in charging the suspect or defendant, the court having to exclude his statement from the means of evidence it uses in order to retain the existence of a reasonable suspicion regarding the committing of a criminal offence.

Similarly, the sanction of the exclusion of evidence must also apply to equally produced evidence, based on information obtained from unlawfully produced evidence (derived evidence), the application of the doctrine of the "remote effect" or "fruit of the poisonous tree" (fruit of the poisonous tree) becoming thus necessary.

We believe that if, through the violation of the right to silence and to avoid selfincrimination, evidence has been unlawfully or unfairly produced, and from such evidence have resulted facts and circumstances which have directly and necessarily led the bodies of criminal prosecution to lawfully producing other evidence (the production of the illegal means of evidence being a sine qua non condition for the production of the lawful means of evidence), the latter are to be excluded, and that the courts cannot ground their decision on such derived evidence.

\section{Purpose of the privilege of silence within the meaning of the ECHR}

The source of the legal provisions provided by Art. 83 letter (a) of the New Criminal Procedure Code is to be found in the international acts relevant for the criminal proceedings: The International Covenant on Civil and Political Rights ${ }^{13}$, which provides in Art. 14 point (3) that "any person accused of committing a criminal offence shall be entitled not to be compelled to testify against himself or to confess guilt”. Article 55 of the Statute of the International Criminal Court $^{16}$ establishes that, in an investigation initiated on the basis of the Statute, a person is not under the obligation to testify against himself or to confess his own guilt.

There is a rich jurisprudence of the European Court of Human Rights (ECHR) as determined by art. 6 (2) of the Convention. In Funke v. France, the Court found a violation of the right of the person to be silenced by a request for the provision of precisely identified documents, namely: the extract from his bank accounts abroad, under threat of penal sanctions in case of

\footnotetext{
12 See M. Duţu (2004), Op. cit., 185; Gh. Radu (2017), Măsurile preventive în procesul penal român [Prevention measures in the Romanian criminal procedural regulation], Bucharest, Hamangiu Publishing House, 77.

${ }_{13}$ The European Court of Human Rights, Case Allan $v$. The United Kingdom, judgment of 5 November 2002. "Fruit of the Poisonous Tree" is a legal metaphor used in the U.S.A. to describe the fact that the evidence was obtained illegally. The logic of using this terminology is that the source (the "tree") of the piece or pieces of evidence is itself poisonous, therefore whatever comes from that source (the "fruit") is also poisonous. The International Covenant on Civil and Political Rights, adopted on 16 December 1966 in New York, in force as of 23 March 1966, adopted in Rome on 17 July 1998.
} 
refusal ${ }^{17}$.

In the case Allan $v$. The United Kingdom, the ECHR set out a number of requirements and considerations regarding the right to silence in the context of a fair trial. If the accused has been intercepted in violation of his right to silence, his actual possibility of challenging the authenticity of the evidence and of opposing the use thereof according to the principle of contradiction should be achieved, to the extent that the applicant's admissions [occurred] in the course of his own conversation conducted voluntarily, as an expression of reality, without there being any trap or another activity meant to give rise to such confessions, [while also considering] the quality of the evidence, including the determination of whether the circumstances in which the confession was obtained raises doubts regarding its reliability or accuracy ${ }^{13}$. In the same case, the Court recalls that the petitioner's words being recorded at the police station and the penitentiary, performed when he was in the company of his accomplice (in other offences), of his [girl]friend and of the police informant, as well as the testimony of the informant constitute the main evidence of the prosecution against him. The ECHR remarks, firstly, that the materials obtained through audio and video recordings are not illegal, and are not contrary to domestic law. There is no indication of the fact that the admissions made by the applicant while talking to his accomplice or his [girl]friend were not voluntary, in the sense of him being coerced or deceived into making those statements, since he might have been aware of the possibility of being recorded at the police station. The Court established that it was not convinced that the use of the materials regarding the accomplice and the friend was contrary to the requirements regarding a fair trial provided by Art. 6 of the European Convention.

The purpose of the privileges against self-incrimination is, in the Court's view, to protect the accused from inappropriate actions of the authorities and, thus, to avoid judicial errors. The right to non-self-incrimination is primarily aimed at respecting the accused person's will to remain silent and assumes that, in criminal cases, the prosecution has the burden of proof against the accused, without obtaining the evidence by coercive or oppressive methods, against the accused person's will ${ }^{14}$.

The Court recalls that, even if Art. 6 of the Convention does not expressly mention the right to remain silent and one of its components - the right not to contribute to one's own incrimination, it is, however, proved by its presence in the recognized international norms which lie at the centre of the notion of a fair trial, as enshrined by this Article ${ }^{15}$. The Court also points out that, in this case, the reasons for which this right exists in international rules, are in particular related to the need to protect the accused against the application of abusive coercive force by the authorities, which leads to the avoidance of judicial errors and allows for the goals stipulated by Art. 6 of the European Convention on Human Rights to be achieved. In particular, the right not to contribute to one's own incrimination presupposes that, in a criminal case, the prosecution seeks to ground its argumentation without recourse to evidence, obtained through coercion or pressure, against the will of the accused. It has rightly been shown in the doctrine that the prosecution bodies are obliged, as soon as the commission of the flagrant offence has been established, to inform the perpetrator about his rights to defend himself, including the right to silence $^{16}$. This right is closely related to the principle of the presumption of innocence enshrined in Art. 6 par. (2) of the Convention. At the same time, the right not to incriminate himself primarily refers to respecting the decision of an accused to remain silent.

${ }_{14}$ The European Court of Human Rights (1996), Case Saunders $v$. The United Kingdom, judgment of 17 December 1996.

15 Ibid.

${ }^{16}$ C. S. Paraschiv and M. Damaschin (2005), Dreptul învinuitului de a nu se autoincrimina [The Right of the Accused Against Self-incrimination], Dreptul (Law), No. 2, 145. 
What is understood as common to the legal systems does not extend to the use, in the criminal proceedings, of data which could be obtained from the accused by recourse to coercive forces, but which exist independently of the suspect's will, such as documents obtained on the basis of a warrant, determining the state of inebriation, collecting blood and urine, as well as body tissues in view of performing DNA tests.

It should be noted, however, that it is possible to formulate reasonings that are unfavourable to the silence of an accused during the proceedings. In the case John Murray $v$. The United Kingdom ${ }^{17}$, the European Court states that "the right to remain silent is not an absolute right”. Even though it is incompatible with such immunity to base a conviction solely or mainly on the accused's silence or on his refusal to answer questions, it is obvious that this privilege does not prevent an accused's silence being taken into account in situations which clearly call for an explanation from him.

In the case Condron $v$. The United Kingdom ${ }^{18}$, the Court ruled that jurors should receive from the judge appropriate instructions regarding conclusions to the detriment of an accused, which may result from his silence. Otherwise, drawing conclusions from the silence of the person concerned constitutes a violation of Art. 6 of the Convention.

The Court has also ruled on several instances of use of police informants ${ }^{19}$ in a number of cases, and the Court has retained that the right to silence and the privilege against selfincrimination primarily have the role of protecting against inappropriate actions by the authorities and against obtaining evidence by coercive or oppressive methods, which are contrary to the will of the accused. The scope of the right is not limited to cases in which the accused has suffered or has been made to suffer directly in any way. This right, which the Court has retained as a part of the notion of fair trial, serves, in principle, to the protection of the freedom of a person called to choose whether to answer or not the questions of the police. This freedom of choice is undermined in cases where the suspect having chosen to remain silent during interrogations, the authorities resort to the subterfuge of obtaining testimonies from the suspect or other incriminating statements which they were not able to obtain during the interrogations, and these testimonies or statements are presented as evidence in the trial. The assessment, in this case, of the extent to which the undermining of the right to silence constitutes a violation of Art. 6 of the Convention, depends on the circumstances of the individual case. The Court notes that, in the interrogations, the applicant, following the advice of his lawyer, has constantly chosen to remain silent. An arrested person, who had been a long-time police informant, was placed in the cell of the applicant, in order to obtain information from him about his involvement in committing the crime he was suspected of.

The evidence presented in the trial indicates that the informant was instructed by the police to make him confess, so that the decisive evidence in the prosecution obtained in this way was not produced spontaneously, voluntarily, but was determined by the persistent questions of the informant who, under the guidance of the police, channeled the discussion towards the circumstances of the offence.

This can be regarded as a functional equivalent of an interrogation, but in the absence

${ }_{17}$ The European Court of Human Rights (1996), Case John Murray $v$. The United Kingdom, judgment of 8 February 1996, 47.

18 The European Court of Human Rights (1999), Case Condron v. The United Kingdom, judgment of 29 September 1999.

19 The European Court of Human Rights (2000), Case Heaney and McGuinness v. Ireland, judgment of 21 December 2000; The European Court of Human Rights (2001), Case J.B. v. Switzerland, judgment of 3 May 2001, quoted by V. Dabu and A.-M. Guşanu (2004), Reflecţii asupra dreptului la tăcere [Reflections on the Right to Silence], Revista de Drept Penal (Criminal Law Journal), No. 4: 71-72. 
of any form of protection which exists in the case of a formal police interrogation, including the presence of a lawyer and the usual warnings. The Court considers that the applicant was subjected to psychological pressures that also influenced the "voluntary" character of the applicant's statements made to the informant: he was being held in detention, suspected of murder; being under the direct pressure of police interrogations with regard to the murder, he proved to be susceptible to persuasion by the informant, with whom he shared the same cell for several weeks, into confiding in him. Under the circumstances, the information obtained by using the informant in such a way can be regarded as contrary to the accused person's right to silence and privilege against self-incrimination. Therefore, Art. 6 point (1) of the Convention was violated in this respect.

In a number of cases related to the conduct of police interrogations, the judges in Strasbourg identified some violations of Art. 6; when incriminating statements, obtained from a suspect who had been deprived of any contact with the outside under oppressive detention conditions and without access to a lawyer, had been used in the trial ${ }^{20}$. The Court adopted an identical position with regard to statements or evidence obtained by using questionable methods without taking into account their use before the court (the case Heaney and Mc Guinness $v$. Ireland), in which case the applicants obtained contradictory information about their rights during police interrogations, which compelled them to give up their right to remain silent ${ }^{21}$.

The examination of petitions with regard to the use of undercover agents in the proceedings holds a special place. In the case of Liidi $v$. Switzerland, the Court did not find any violation of the right to a fair trial because the undercover agent concerned was under oath, the investigating judge was aware of his mission and the authorities opened a preliminary investigation against the petitioner. The Court concluded to the contrary in the case Teixeira de Castro $v$. Portugal, where the police acted outside any judicial control, the applicant having no criminal record, which is not an obstacle to the conduct of a criminal investigation.

It should be noted that there is a link between statements of admission of guilt obtained through coercion and unfavourable conclusions elicited by illegal methods from a suspect, thus violating his right to remain silent. ${ }^{22}$ The Court established there was a violation of Art. 6 par. (2) if the court acknowledged the applicants' guilt on the ground that they had refused to answer the questions of the police (case Heaney and McGuinness $v$. Ireland, and case Quinn $v$. Ireland). Even though the applicant was not criminally punished for his refusal to answer the questions, there was a violation of Art. 6 par. (2) of the Convention starting from the moment when the police communicated to him contradictory or obscure information about his right to remain silent, especially if his lawyer did not attend the interrogations (case Averill $v$. The United Kingdom).

In another case, Condron $v$. The United Kingdom, the Court found that the communication of inappropriate instructions to jurors as to the nature of the conclusions that may be drawn from the silence of a suspect during his interrogation by the police constitutes an infringement of Art. 6, insofar as that procedural flaw has not been repaired in the appeal; the applicant had been detained and interrogated while suffering the effects of heroin deprivation ${ }^{23}$.

\footnotetext{
${ }^{20}$ The European Court of Human Rights (2000), Case Magee $v$. The United Kingdom, judgment of 6 June 2000.

${ }^{21}$ D. Gomien (2006), Ghid al Convenţiei Europene a Drepturilor Omului [Guide to the European Convention on Human Rights], $3^{\text {rd }}$ Edition, Chişinău, 66

22 Ibid.

23 Ibid., 67.
} 
4. The witness's right not to incriminate himself

An element of novelty in our domestic legislation but which is extremely often resorted to in international legislation is the use by the witness of the right to silence and that of not contributing to his own incrimination.

The New Criminal Procedure Code, in Art. 114 par. (1), defines the notion of witness as being "any person who has knowledge of the facts or factual circumstances constituting evidence in a criminal case".

The notion requires the following clarifications provided for in par. (2) of the same Article: "any person summoned as a witness has the obligation to appear before the judicial body that summoned him at the location, on the day and at the time indicated in the summons, to take an oath or a make a solemn declaration before the court and to tell the truth".

According to Art. 6 par. 3 letter d) of the European Convention, "everyone charged with a criminal offence has, in particular, the right to examine or have examined witnesses against him and to obtain the attendance and examination of witnesses on his behalf under the same conditions as witnesses against him", thus being ensured compliance with the principle of contradiction in the criminal proceedings. In several judgments, the European Court has emphasized that the notion of witness has an autonomous meaning in the context of the Convention ${ }^{24}$. Insofar as a statement, whether made by a witness within the strict meaning of the word, or made by a co-defendant, is likely to substantiate the conviction of the accused, it is a testimony for the prosecution ${ }^{25}$. The Court also included the civil party in the notion of witness, taking as a starting point the defendant's right in a fair trial to challenge the civil party's statements ${ }^{26}$.

Within the meaning of Art. 6 par. 3 letter (d) of the Convention, an expert was also recognized as having the capacity of witness when, in a public action, he approaches the legal position of a witness in the prosecution. There are different notions used in the Court's case-law which have the meaning of witness in cases where the principle of proportionality imposes the need either for protecting witnesses, or for maintaining their anonymity.

In order to determine the notion of witness, it should be noted that, starting from the need to protect vulnerable witnesses and victims, the European Court has shown the following: although Art. 6 does not expressly impose the protection of victims and witnesses, their interests, especially their life, freedom, safety, must be taken into account and, therefore, the States are obliged to protect those interests. In some cases, the nature of the offences is also important for the protection of vulnerable witnesses ${ }^{27}$. In a large number of cases, the phrase anonymous witnesses is used, when it comes to using them for the production of evidence for the indictment, the fact being also mentioned in the legal doctrine. It has been shown that anonymous witnesses

24 The European Court of Human Rights (1991), Case Asch v. Austria, judgment of 26 April 1991; the European Court of Human Rights (2001), Case Luca v. Italy, judgment of 27 February 2001.

${ }_{25}$ For example, the European Court of Human Rights (2002), Case Allan $v$. The United Kingdom, judgment of 5 November 2002.

${ }^{26}$ The European Court of Human Rights (1989), Case Bricmont $v$. Belgium, judgment of 7 July 1989.

${ }^{27}$ For example, in the case Mayoli $v$. France, judgment of 14 June 2005, the Court accepted that in cases involving sexual abuse, certain measures should be taken to protect the victim. In particular, such protection is important in the case of minors. In another case, Bocas-Cuesta $v$. The Netherlands, judgment of 20 November 2006, the Court mentioned that it is important for the the criminal proceedings to be carried out in such a way as to protect the interests of very young minors, especially in cases involving sex offences. However, in both cases cited above, the Court found there had been a violation of Art. 6 par. (1) and par. (3) letter (d) of the Convention by failing to observe the proportionality of the measures applied and the right of the accused person. 
are people who have been heard by protecting their identity or by including them in special protection programmes and who have made statements about the facts of which the respective person is accused ${ }^{28}$. In its case-law ${ }^{29}$, the Court has shown that the use of anonymous witnesses is not incompatible with the provisions of the Convention. The court also includes in the notion of anonymous witnesses infiltrated agents from the police bodies, who, unlike other disinterested anonymous witnesses or the victims of the crimes, have a general duty to be subordinated to the authorities. They can be used with the preservation of anonymity for their own protection and that of their families, as well as in order to avoid compromising their use in future operations.

In the Court's case law there is also mention of the notion of provocative agents who are agents infiltrated by the State or any person acting under the coordination or supervision of an authority ${ }^{30}$ whose intervention should also be supported by guarantors ${ }^{31}$.

We conclude that the witness's right to refuse to file statements should not be affected by the need to establish the truth. The witness must have the right to assess whether, in a given situation, making a testimony can put his or her safety at risk. From another standpoint, the witness's right to refuse to testify should not be absolute. We consider that the witness who is called to court should give reasons for his refusal, and the court, considering the circumstances of the case, should decide either to accept the witness's refusal to testify or to apply the necessary measures of protection.

Thus, with the entry into force of the new Criminal Procedure Code, in our country, too, the witness now enjoys the right to remain silent and not to contribute to his own incrimination, insofar as, by making a statement, he might incriminate himself. Cases where, as a result of successive severances, a suspect or defendant in the initial file becomes a witness in a case file severed from the former file, he can enjoy, in this capacity, the right to silence and to avoid self-incrimination with regard to matters which, once reported, could incriminate him in the case file in which he is an accused.

This right was expressly enshrined in Art. 118 of the New Criminal Procedure Code, according to which the witness statement made by a person who, in the same case, had the capacity of suspect or defendant prior to such testimony or acquired it subsequently, may not be used against him. The judicial bodies have the obligation to mention, at the time of recording the statement, the previous legal standing of the witness. In this case, too, the witness is not under the obligation to make statements, and if he refuses to do so, he cannot be held responsible for committing the offence of false testimony.

It is also worth mentioning that the witness's refusal to testify can be conditioned not only by the assumed danger, but also by the risk of compromising himself. In this respect, it is particularly difficult or quite impossible to determine in the law all the situations in which the witness would have the right to refuse testimonies by invoking the argument of the risk of

\footnotetext{
${ }_{28}$ O. Predescu and M. Udroiu (2007), Convenţia Europeană a Drepturilor Omului şi Dreptul Procesual Penal [European convention on human rights and criminal procedural law], Bucharest, C.H. Beck Publishing House, 455 .

29 For example, the European Court of Human Rights (1989), Case Kostowsky v. The Netherlands, judgment of 20 November 1989. The European Court of Human Rights (1996), Case Doorson v. The Netherlands, judgment of 26 March 1996; The European Court of Human Rights (1997), Case Van Mechelen v. The Netherlands, judgment of 23 April 1997; The European Court of Human Rights (2002), Case Visser v. The Netherlands, judgment of 14 February 2002; The European Court of Human Rights (2006), Case Krasniki $v$. Czech Republic, judgment of 28 February 2006.

30 O. Predescu and M. Udroiu (2007), Op. cit., 464.

${ }^{31}$ The European Court of Human Rights (1992), Case Liidi v. Switzerland, judgment of 15 June 1992; the European Court of Human Rights (1998), Case Teixeira de Castro v. Portugal, judgment of 9 June 1998.
} 
compromising himself.

According to Art. 115 of the New Criminal Procedure Code, "any person may be summoned and heard as a witness, except for the parties and the main trial subjects". Therefore, the person who is itself the object of the investigation should be excluded from the category of persons susceptible of being witnesses. However, in practice, there are frequent cases where a person provides relevant information regarding the role of the accomplices in the given case. In addition to the fact that those persons require protection, the issue of their responsibility for false indiction statements is raised.

Thus, the legislator did not admit the possibility of drawing in the defendant as a witness. From this standpoint, two issues can be brought into discussion: the first concerns the use of a perpetrator as a witness without certain direct legal consequences regarding the penalty to be applied or other matters relating to his future fate; the second refers to either the decision not to prosecute the person or to reduce their penalty. In the former case, we are faced with the classical situation of a person who makes statements about his accomplices hoping that the court will consider that such a statement should have consequences on the penalty to be applied, recognizing this fact as a mitigating circumstance. The latter case refers to certain procedural institutions that would be used depending on the degree of co-operation of the accused. Currently, the institution of the guilty plea (Articles 478-488 of the New Criminal Procedure Code) introduced by the new Criminal Procedure Code is being used.

A person who is a defendant in another criminal case can also participate as a witness in the criminal trial. In addition to the right to silence of the accused, the person is also protected by the immunity from being sanctioned for his refusal to cooperate with the authorities.

Finally, the person executing a custodial sentence may also participate as a witness. This is a person who has been punished by imprisonment either in the same case or in another case.

\section{Conclusions}

The right to silence enjoys increased attention from the Romanian legislator and is currently regulated by the Criminal Procedure Code (Law no. 135/2010), which entered into force on $1^{\text {st }}$ February 2014; the elements of absolute novelty are rectifying the internal regulations that have become incompatible with the current reality and with the European and international regulations in the matter, aligning the Romanian legislation with the latter ones, including in the matter of the right to silence and of the privilege against self-incrimination.

\section{Acknowledgements}

This research did not receive any specific grant from funding agencies in the public commercial, or not-for-profit sectors.

The author declares no competing interests. 


\section{References}

Crişu, A. (2011). Drept procesual penal (Criminal procedural law), $2^{\text {nd }}$ Edition. Bucharest: Hamangiu Publishing House.

Duţu, M. (2004). Semnificaţiile procedural penale ale dreptului la tăcere [The criminal procedural significance of the right to silence]. Dreptul (Law), No. 12.

Gomien, D. (2006). Ghid al Convenţiei Europene a Drepturilor Omului - $3^{\text {rd }}$ Edition [Guide to the European Convention on Human Rights]. Chişinău.

Griga, I., \& Ungureanu, M. (2005). Dreptul la tăcere al învinuitului sau inculpatului (The Right to Silence of the Accused or the Defendant). R.D.P. (Criminal Law Journal), No. 1.

Ionescu, D. (2006). Procedura avertismentului. Consecinţe în materia validităţii declaraţiilor acuzatului în procesul penal [The Warning Procedure. Consequences for the Validity of the Accused's Statements in the Criminal Trial], C.D.P. (Criminal Law Notebooks), No. 2.

Ionescu, D. (2006). Procedura avertismentului. Consecinţe în materia validităţii declaraţiilor acuzatului în procesul penal [The Warning Procedure. Consequences for the Validity of the Accused's Statements in the Criminal Trial]. C.D.P. (Criminal Law Notebooks), No. 2.

LaFave, W. R., \& Israel, J.H. (1992). Criminal Procedure, $2^{\text {nd }}$ edition. West Publishing Co.

Neagu, I. (2015). Drept procesual penal. Partea generală Tratat [Criminal procedural law. The general part. A treatise]. Bucharest: Global Lex.

Paraschiv, C. S., \& Damaschin, M. (2005). Dreptul învinuitului de a nu se autoincrimina" [The Right of the Accused Against Self-incrimination]. Dreptul (Law), No. 2.

Predescu, O., \& Udroiu, M. (2007). Convenţia Europeană a Drepturilor Omului şi Dreptul Procesual Penal [European Convention on Human Rights and Criminal Procedural Law], Bucharest, C.H. Beck Publishing House.

Radu, Gh. (2007). Măsurile preventive în procesul penal român [Prevention Measures in the Romanian Criminal Procedural Regulation]. Bucharest: Hamangiu Publishing House.

Theodoru, Gr. (2013). Drept procesual penal [Criminal procedural law], $3^{\text {rd }}$ Edition Bucharest: Hamangiu.

Trechsel, S. (2006). Human rights in criminal proceedings. Oxford: Oxford University Press.

The High Court of Cassation and Justice of Romania (I.C.C.J.) (2003). Criminal Division, Decision No. 1877/2003, available on the website www.scj.ro.

The Supreme Court of the United States of America (1966). Judgment of 13 $3^{\text {th }}$ July 1966, in the case Miranda $v$. Arizona, available on the website www.supremecourtuk.gov.

The European Court of Human Rights (1989). Case Bricmont v. Belgium, judgment of $7^{\text {th }}$ July 1989, available on the website www.echr.coe.int.

The European Court of Human Rights (1989). Case Kostowsky v. The Netherlands, judgment of $20^{\text {th }}$ November 1989, available on the website www.echr.coe.int.

The European Court of Human Rights (1991). Case Asch $v$. Austria, judgment of $26^{\text {th }}$ April 1991, available on the website www.echr.coe.int.

The European Court of Human Rights (1992). Case Liidi $v$. Switzerland, judgment of $15^{\text {th }}$ June 1992, available on the website www.echr.coe.int.

The European Court of Human Rights (1996). Case Saunders $v$. The United Kingdom, judgment of $17^{\text {th }}$ December 1996, available on the website www.echr.coe.int. 
The European Court of Human Rights (1996). Case John Murray $v$. The United Kingdom, judgment of $8^{\text {th }}$ February 1996, available on the website www.echr.coe.int.

The European Court of Human Rights (1996). Case Doorson $v$. The Netherlands, judgment of $26^{\text {th }}$ March 1996, available on the website www.echr.coe.int.

The European Court of Human Rights (1997). Case Van Mechelen $v$. The Netherlands, judgment of $23^{\text {rd }}$ April 1997, available on the website www.echr.coe.int.

The European Court of Human Rights (1998). Case Teixeira de Castro $v$. Portugal, judgment of $9^{\text {th }}$ June 1998, available on the website www.echr.coe.int.

The European Court of Human Rights (1999). Case Condron $v$. The United Kingdom, judgment of 29 September 1999, available on the website www.echr.coe.int.

The European Court of Human Rights (2000). Case Magee $v$. The United Kingdom, judgment of $6^{\text {th }}$ June 2000, available on the website www.echr.coe.int.

The European Court of Human Rights (2000). Case Heaney and McGuinness $v$. Ireland, judgment of $21^{\text {st }}$ December 2000, available on the website www.echr.coe.int.

The European Court of Human Rights (2001). Case J.B. v. Switzerland, judgment of $3^{\text {rd }}$ May 2001, available on the website www.echr.coe.int., quoted by V. Dabu \& A.-M. Guşanu (2004). Reflecţii asupra dreptului la tăcere [Reflections on the Right to Silence]. Revista de Drept Penal (Criminal Law Journal), No. 4.

The European Court of Human Rights (2001). Case Luca $v$. Italy, judgment of $27^{\text {th }}$ February 2001, available on the website www.echr.coe.int.

The European Court of Human Rights (2002). Case Allan $v$. The United Kingdom, judgment of $5^{\text {th }}$ November 2002, available on the website www.echr.coe.int.

The European Court of Human Rights (2002). Case Allan $v$. The United Kingdom, judgment of $5^{\text {th }}$ November 2002, available on the website www.echr.coe.int.

The High Court of Cassation and Justice of Romania (ICCJ) (2006). Criminal Division, Decision No. 828/2006, available on the website www.scj.ro.

April 1997, available on the website www.echr.coe.int.

The European Court of Human Rights (2002). Case Visser $v$. The Netherlands, judgment of $14^{\text {th }}$ February 2002, available on the website www.echr.coe.int.

The European Court of Human Rights (2006). Case Krasniki v. Czech Republic, judgment of $28^{\text {th }}$ February 2006, available on the website www.echr.coe.int.

The European Court of Human Rights (2014). Case Cesnieks $v$. Latvia, judgment of $11^{\text {th }}$ February 2014, available on the website www.echr.coe.int.

http://eur-lex.europa.eu. 